\title{
A SURVEY ON TOOLS USED FOR MACHINE LEARNING
}

Dr. S. Veena

Professor,

Department of CSE

S.A. Engineering College, Thiruverkadu, Chennai,

Tamil Nadu, India.
T. Shankari

UG Student,

Department of CSE

S.A. Engineering College, Thiruverkadu, Chennai,

Tamil Nadu, India.

ABSTRACT:- In this paper, a brief introduction to Machine Learning and its Tools are studied. In the recent developments, most of the Machine learning tools are more advanced and efficient. The various tools learn the machine by using a training set, which predicts the output correctly and efficiently. Machine Learning is applied in different applications such as Agriculture, Data Quality, Information Retrieval, Financial Market Analysis etc.., In this paper, we have discussed few tools like Scikit learn, Pytorch, Tensor flow, Amazon Machine Learning, KNIME, Rapid Miner, Keras, and Shogun with its features and its advantages.

Keywords : Machine Learning, Model, Types of Learning, Applications

\section{INTRODUCTION}

Machine Learning is the Scientific study of Algorithms and statistical models to perform a specific task without explicit instruction instead uses patterns and inference. It is widely seen as a Subset of Artificial Intelligence(AI). The name Machine learning was proposed by Arthur Samuel in 1959. Tom M.Mitchell provided a formal definition of Algorithms as "A computer program is said to learn from experience $\mathrm{E}$ with respect to some class of tasks $\mathrm{T}$ and performance measure $\mathrm{P}$ if its performance at tasks in $\mathrm{T}$, as measured by P, improves with experience E." Numerous Machine Learning Algorithms have been around for a long time, the ability to carry out complex mathematical calculations in big data and deliver faster and more accurate results.

\section{TYPES OF MACHINE LEARNING}

Machine Learning can be broadly classified into three main categories,

\author{
S. Sowmiya \\ UG Student, \\ Department of CSE
}

S.A. Engineering College,

Thiruverkadu, Chennai,

Tamil Nadu, India.

They are,

\section{Supervised Learning \\ Unsupervised Learning}

Reinforcement Learning

Supervised Learning needs to be guided, Unsupervised Learning Learns from the Observation and finds it's Data Structure but Reinforcement Learning directly interact with the environment and Follows Hit and Trial Method. Machine Learning tools are the Artificial Intelligence-Algorithmic Applications that provide Systems the ability to understand and improve without considerable human Input.

\section{Machine Learning Tools consists of \\ - Preparation and Data Collection \\ - Building Models \\ - Application Deployment and Training.}

Machine Learning Tools can be broadly classified based on Platforms And Libraries. A Machine Learning Platform provides capabilities to complete a machine learning project from beginning to end where as the Machine Learning Libraries provides capabilities to complete a part of machine learning project.

In Supervised Learning, the history of data can be sued to make predictions. These predictions are more accurate. Regression and Classification algorithms falls under the Supervised Learning. The Unsupervised Learning used to find the hidden patterns. Clustering and Association rule mining algorithms comes under this type of learning. When the system need to improve the efficiency then the Reinforcement learning can be used. 
International Journal of Engineering Applied Sciences and Technology, 2020

Vol. 4, Issue 9, ISSN No. 2455-2143, Pages 116-119

Published Online January 2020 in IJEAST (http://www.ijeast.com)

III. COMPARISON OF VARIOUS TOOLS IN MACHINE LEARNING

\begin{tabular}{|c|c|c|c|}
\hline TOOL NAME & FEATURES & ALGORITHMS & ADVANTAGES \\
\hline $\begin{array}{l}\text { SCIKIT } \\
\text { LEARN[7] }\end{array}$ & $\begin{array}{l}\text { It provides machine learning } \\
\text { development libraries for python } \\
\text { language } \\
\text { - It is also used in data mining and } \\
\text { data analysis. }\end{array}$ & $\begin{array}{ll}\text { - } & \text { Classification } \\
\text { - } & \text { Clustering } \\
\text { - } & \text { Regression } \\
\text { - } & \text { Dimensionality } \\
& \text { reduction }\end{array}$ & $\begin{array}{l}\text { - Easily understandable } \\
\text { documentation } \\
\text { - } \quad \text { Parameters for any specific } \\
\text { algorithms can be altered }\end{array}$ \\
\hline PYTORCH[10] & $\begin{array}{l}\text { Pytorch is a torch based machine } \\
\text { learning library in python which is } \\
\text { used on cloud platforms. } \\
\text { - It is used for building neural } \\
\text { networks through autograde } \\
\text { module. } \\
\text { - It provides optimization algorithms } \\
\text { for neural networks }\end{array}$ & - Neural Network & $\begin{array}{l}\text { - It helps in creating } \\
\text { computational graphs. } \\
\text { It has hybrid front end which } \\
\text { makes usage comfortable. }\end{array}$ \\
\hline $\begin{array}{l}\text { GOOGLE } \\
\text { CLOUD ML } \\
\text { ENGINE[11] }\end{array}$ & $\begin{array}{l}\text { - It is a machine learning tool to } \\
\text { create and run the optimum quality } \\
\text { models. } \\
\text { It provides two services namely, } \\
\circ \text { Prediction } \\
\circ \quad \text { Training }\end{array}$ & $\begin{array}{ll}\text { - } & \text { Naïve Bayes } \\
& \text { Classifier }\end{array}$ & $\begin{array}{l}\text { - Most suitable for enterprises. } \\
\text { - It can be used to train a } \\
\text { complex model }\end{array}$ \\
\hline $\begin{array}{l}\text { TENSOR } \\
\text { FLOW[12] }\end{array}$ & $\begin{array}{l}\text { - Tensor flow is a Java script library } \\
\text { for machine learning. } \\
\text { - It works as a model converter as it } \\
\text { is used to run existing models. }\end{array}$ & $\begin{array}{ll}- & \text { Libraries for } \\
\text { Data flow } \\
\text { - } \\
\text { Deep learning }\end{array}$ & $\begin{array}{l}\text { - It can be used either as script } \\
\text { tags or by installing through } \\
\text { NPM. } \\
\text { - It helps for human pose } \\
\text { estimation. }\end{array}$ \\
\hline $\begin{array}{c}\text { AMAZON } \\
\text { MACHINE } \\
\text { LEARNING[13] }\end{array}$ & $\begin{array}{l}\text { Amazon machine learning is a } \\
\text { cloud based and robust machine } \\
\text { learning tool } \\
\text { - Fundamental modes are ML } \\
\text { models, Real time prediction } \\
\text {,evaluations and batch predictions }\end{array}$ & $\begin{array}{ll}\text { - } & \text { Linear } \\
\text { Regression, } \\
\text { - } \\
\text { Logistic } \\
\text { Regression, } \\
\text { Multinominal } \\
\text { Logistic } \\
\text { Regression }\end{array}$ & $\begin{array}{l}\text { - Permits user to create data } \\
\text { source object form MySQL. }\end{array}$ \\
\hline KNIME[7] & $\begin{array}{l}\text { - KNIME is a tool for data analytics, } \\
\text { reporting and integration platform. } \\
\text { - It uses data pipelining concept. } \\
\text { - It is used to integrate the } \\
\text { programming languages like C, } \\
\text { C++, R, PYTHON, JAVA. } \\
\text { - It is a Graphical user interface }\end{array}$ & $\begin{array}{ll}- & \text { Text Mining } \\
- & \text { Image Mining }\end{array}$ & $\begin{array}{l}\text { - It is an alternative for SAS. } \\
\text { - } \quad \text { Easy to learn. } \\
\text { - }\end{array}$ \\
\hline
\end{tabular}


Published Online January 2020 in IJEAST (http://www.ijeast.com)

\begin{tabular}{|c|c|c|c|}
\hline TOOL NAME & FEATURES & ALGORITHM & ADVANTAGES \\
\hline $\begin{array}{c}\text { RAPID } \\
\text { MINER[14] }\end{array}$ & $\begin{array}{l}\text { - Rapid miner is a } \\
\text { platform for machine } \\
\text { learning ,deep learning. } \\
\text { It helps in designing } \\
\text { and analytical } \\
\text { workflows through } \\
\text { graphical user interface } \\
\text { (GUI). } \\
\text { Model validation and } \\
\text { optimization is done. }\end{array}$ & $\begin{array}{ll}- & \text { Logistic } \\
& \text { Regression } \\
- & \text { Linear Regression } \\
\text { - } & \text { LARS }\end{array}$ & $\begin{array}{l}\text { - Extensible through plugins. } \\
\text { - } \\
\text { - } \\
\text { No pro of use } \\
\text { required. }\end{array}$ \\
\hline KERAS[7] & $\begin{array}{l}\text { - Keras is an API for } \\
\text { neural networks which } \\
\text { is a subset of machine } \\
\text { learning. } \\
\text { - It supports convolution } \\
\text { and recurrent networks. } \\
\text { - It can be run on CPU } \\
\text { and GPU. }\end{array}$ & $\begin{array}{ll}\text { - } & \text { Convolutional } \\
\text { networks } \\
\text { - } & \text { Recurrent networks }\end{array}$ & $\begin{array}{l}\text { - It is user friendly } \\
\text { - It is extensible and modular. }\end{array}$ \\
\hline SHOGUN[7] & $\begin{array}{l}\text { - It provides various } \\
\text { algorithms and data } \\
\text { structures for machine } \\
\text { learning. } \\
\text { It supports in } \\
\text { implementing Hidden } \\
\text { markov models. } \\
\text { - It support vector } \\
\text { machines. }\end{array}$ & $\begin{array}{ll}\text { - } & \text { Classification } \\
\text { - } & \text { Clustering } \\
\text { - } & \text { Regression } \\
\text { - } & \text { Support Vector } \\
& \text { Machine } \\
\text { - } & \text { Dimensionality } \\
& \text { Reduction }\end{array}$ & $\begin{array}{l}\text { - It is a unified and efficient } \\
\text { machine learning library. } \\
\text { - It can process large set of } \\
\text { data. } \\
\text { - User friendly and provides } \\
\text { good customer support. }\end{array}$ \\
\hline WEKA[7,16] & $\begin{array}{l}\text { WEKA is Waikato } \\
\text { Environment for } \\
\text { Knowledge Analysis . } \\
\text { It is a software program } \\
\text { which has a collection } \\
\text { of machine learning } \\
\text { algorithms to perform } \\
\text { data mining tasks. } \\
\text { - It is an open source } \\
\text { Java based platform } \\
\text { It consists of a } \\
\text { visualization tool to } \\
\text { perform data analysis } \\
\text { and predictive } \\
\text { modeling. }\end{array}$ & $\begin{array}{ll}\text { - } & \text { Classification } \\
\text { - } & \text { Clustering } \\
\text { - } & \text { Regression } \\
\text { - } & \text { Association Rule } \\
\text { - } & \text { Vining } \\
\end{array}$ & $\begin{array}{l}\text { The package in WEKA has } \\
\text { an integration of the three } \\
\text { entities such as data } \\
\text { preparation, feature selection } \\
\text { and data mining algorithms. } \\
\text { - It is a open source under } \\
\text { GPU. } \\
\text { - It is portable as it is written } \\
\text { in Java. }\end{array}$ \\
\hline
\end{tabular}




\section{APPLICATIONS}

Web Search Engine, Photo Tagging Applications and Spam Detector are the major applications of machine learning. It also used in the field of Medical Diagnosis, Speech and Image recognition, Statistical Arbitrage, Learning Association, Prediction, Classification, Extraction and Regression.

\section{CONCLUSION}

Machine learning is an incredible breakthrough in the field of artificial intelligence. Although machine learning has been transformative in some fields, but its programs fail to deliver expected results in some way. This may cause due to lack of respective data, lack of access to the data, data bias, privacy problems, badly chosen tasks and algorithms, wrong tools and people, lack of resources and evaluation problems.

\section{ACKNOWLEDGEMENT}

We would like to thank our Management, Advisor and Principal of S.A.Engineering College for constantly motivating us to do research in our work environment and encourages us to publish more research papers.

\section{REFERENCES}

1. Nils J. Nilsson(1996), Introduction to Machine Learning.

2. Trevor Hastie, Robert Tibshirani and Jerome $\mathrm{H}$. Friedman (2001). The Elements of Statistical Learning, Springer. ISBN 0-387-95284-5.

3. Pedro Domingos (September 2015), The Master Algorithm, Basic Books, ISBN 978-0-465-06570-7

4. Ian H. Witten and Eibe Frank (2011). Data Mining: Practical machine learning tools and techniques Morgan Kaufmann, 664pp., ISBN 978-012-374856-0

5. Ethem Alpaydin (2004). Introduction to Machine Learning, MIT Press, ISBN 978-0-262-01243-0.

6. Stuart Russell \& Peter Norvig, (2009). Artificial Intelligence - A Modern Approach. Pearson, ISBN 9789332543515.

7. https://www.softwaretestinghelp.com/machinelearning-tools/

8. https://machinelearningmastery.com/machinelearning-tools/

9. https://www.ubuntupit.com/best-ai-and-machinelearning-software-and-frameworks/

10. https://hub.packtpub.com/what-is-pytorch-andhow-does-it-work/
11. https://towardsdatascience.com/10-most-popularmachine-learning-software-tools-in-2019678b80643ceb

12. https://www.tensorflow.org/js/guide/conversion

13. https://docs.aws.amazon.com/machinelearning/latest/dg/what-is-amazon-machinelearning.html

14. https://rapidminer.com/products/studio/featurelist/

15. https://towardsdatascience.com/data-mining-toolsf701645e0f4c

16. https://www.cs.waikato.ac.nz/ml/weka/ 